\title{
Physico-Chemical and Sensory Evaluation of Wheat Bread Supplemented with Stabilized Undefatted Rice Bran
}

\author{
Michael O. Ameh ${ }^{1}$, Dick I. Gernah ${ }^{2 *}$, Bibiana D. Igbabul ${ }^{2}$ \\ ${ }^{1}$ Department of Nutrition and Dietetics, Federal Medical Centre, Makurdi, Nigeria; ${ }^{2}$ Department of Food Science and Technology, \\ University of Agriculture, Makurdi, Nigeria. \\ Email: "gernah04@yahoo.com
}

Received July $2^{\text {nd }}, 2013$; revised August $2^{\text {nd }}, 2013$; accepted August $9^{\text {th }}, 2013$

Copyright (C) 2013 Michael O. Ameh et al. This is an open access article distributed under the Creative Commons Attribution License, which permits unrestricted use, distribution, and reproduction in any medium, provided the original work is properly cited.

\begin{abstract}
The effect of rice bran supplementation on some physico-chemical and sensory properties of wheat bread was determined. Blends of wheat flour and rice bran $(95: 5,90: 10$ and 85:15) were used to bake bread with $100 \%$ wheat flour as control. Thereafter, proximate, vitamin and mineral composition, as well as the physical and sensory properties of the dough and bread loaves were determined, using standard methods of analysis. The moisture content, crude protein, crude fat, crude fibre and ash of the composite bread loaves increased significantly $(\mathrm{p}<0.05)$ from $21.07 \%$ to $23.67 \%$, $12.04 \%$ to $13.10 \%, 1.57 \%$ to $3.77 \%, 1.76 \%$ to $2.91 \%$ and $1.46 \%$ to $2.41 \%$ respectively; while carbohydrate content decreased with increased level of supplementation from $62.10 \%$ to $54.14 \%$. There were significant increases $(\mathrm{p}<0.05)$ in vitamin $B_{1}$ (Thiamin) from $0.15 \mathrm{mg} / 100 \mathrm{~g}$ to $0.47 \mathrm{mg} / 100 \mathrm{~g}$ and $\mathrm{B}_{2}$ (Niacin) from $3.31 \mathrm{mg} / 100 \mathrm{~g}$ to $4.04 \mathrm{mg} / 100 \mathrm{~g}$ but no significant increase $(\mathrm{p}>0.05)$ in vitamin $\mathrm{B}_{3}$ (Riboflavin). Mineral content of the bread increased significantly $(\mathrm{p}<$ 0.05) with increased level of supplementation from $9.32 \mathrm{mg} / 100 \mathrm{~g}$ to $20.52 \mathrm{mg} / 100 \mathrm{~g}$ (Iron), $80.74 \mathrm{mg} / 100 \mathrm{~g}$ to 188.20 $\mathrm{mg} / 100 \mathrm{~g}$ (Potassium), $81.31 \mathrm{mg} / 100 \mathrm{~g}$ to $130.70 \mathrm{mg} / 100 \mathrm{~g}$ (Calcium) and $13.65 \mathrm{mg} / 100 \mathrm{~g}$ to $132.22 \mathrm{mg} / 100 \mathrm{~g}$ (Magnesium). However, there was a significant decrease $(\mathrm{p}<0.05)$ in sodium with increased level of supplementation from $305.25 \mathrm{mg} / 100 \mathrm{~g}$ to $253.03 \mathrm{mg} / 100 \mathrm{~g}$. Bread loaf weight increased from $152.7 \mathrm{~g}$ to $162.7 \mathrm{~g}$; while loaf volume decreased from $655.2 \mathrm{ml}$ to $586.0 \mathrm{ml}$ and specific loaf volume decreased from $4.29 \mathrm{ml} / \mathrm{g}$ to $3.60 \mathrm{ml} / \mathrm{g}$. There were significant differences $(\mathrm{p}<0.05)$ in physical properties of dough and bread loaves between the composite bread and the control. Though $100 \%$ wheat bread had better acceptability scores (7.95) compared to composite bread (7.20 for 95:5 blend), all the composite bread samples had significantly $(p<0.05)$ higher values for nutritional parameters. There was therefore, a significant improvement in the nutritional composition of the wheat bread with rice bran supplementation.
\end{abstract}

Keywords: Composite Bread; Vitamins; Minerals; Rice Bran; Supplementation

\section{Introduction}

The problems of malnutrition in Nigeria, although different in magnitude and severity among different groups, are due to protein, vitamins, and mineral deficiencies [1]. Since the diet of an average Nigerian consists of foods that are mostly carbohydrate based, there is therefore, need for strategic use of inexpensive high protein and micronutrient food sources that will increase the protein content of the staple diet in order to enhance their nutritive value.

Bread is an important staple food, the consumption of which is steadily increasing in Nigeria due to changing life styles. Nutritionally, bread contains a high percent-

"Corresponding author. age of carbohydrate and fat both of which are needed for energy production. Other nutrients like vitamins, minerals and protein are relatively in small proportion [2]. It is however, relatively expensive, being made from wheat which cannot be cultivated in the tropics for climatic reasons. Wheat importation therefore represents an immense drain on the economy while also suppressing and displacing indigenous cereals, with a resultant detrimental effect on agricultural and technological development.

Recently, the focus of interest and significant efforts has been in the development of food products from byproducts or wastes and under-utilized agricultural products - "wealth from waste" [3]. Apparently, such utilization and development embarks on production of various new food products by maximizing the available re- 
sources to contribute the recommended dietary nutrient intake to fulfill the consumer's expectations. Development of new generation bread products derived from diverse sources of non-wheat flours provides an alternative towards nutritionally richer and cheaper bread products [4]. The objective of supplementing alternative ingredients in bread formulation is to improve the nutritional value of wheat flour particularly proteins, minerals, vitamins and dietary fibre [4]. Formulation of composite flour is vital for development of value added products with optimal functionality [5]. A variety of wheat flour substitutes such as soy or defatted soy flour [6], defatted wheat germ [7], flax seed [8], sunflower seed [9], chempedak seed flour [10], and rice bran [11,12] have been tried in bakery formulation with varying success.

Rice bran, the brown outer layer of rice kernel is mainly composed of pericarp, aleurone/sub-aleurone layers and germ. Currently it is discarded as a waste product during the process of rice milling in this part of the world. However, it is an excellent source of total dietary fiber ranging from $20 \%-51 \%$ [13]. Rice bran fiber has laxative effect with increased fecal output and stool frequencies [14]. It is also a good source of proteins, lipids, vitamins and minerals. Chemically it contains $11 \%-17 \%$ protein, $11 \%-18 \%$ fat, $10 \%$ fibre, $9 \%$ ash and $45 \%$ $65 \%$ nitrogen free extract (NFE). It is a rich source of B-vitamins and minerals such as potassium, calcium, magnesium and iron $[13,15,16]$. The amino acid profile of rice bran has been generally reported to be superior to cereal grain proteins [17]. The low content of saturated fatty acids and high content of linoleic acid, poly-unsaturated fatty acids plus tocopherol makes rice bran oil a health beneficial food [18]. Godber et al. [19] have shown that rice bran and rice bran oil have potential health benefits in the prevention of diseases such as cancer, kidney stones, heart disease and hyperlipidaemia. This is attributed to the high content of gammaryzanol, which is a mixture of ferulate esters of triterpene alcohols [19].

Work done in this area suggests that supplementation of wheat flour with rice bran holds the potential to uplift the nutritional profile of their food products with special reference to protein, lysine and dietary fiber contents [20]. Sharp and Kitchen [11] reported that defatted rice bran increases dough yield, contributes to an attractive crumb and crust, does not disturb fermentation or mixing tolerance of dough, causes baked products to remain fresh, moist and also adds significant amino acids, minerals and vitamins to baked goods. Owing to its composition and apparent hypoallergenicity, rice bran has much application in a diet which may be characterized by high dietary fibre and low saturated fat. It may be particularly beneficial to those individuals who are allergic to other cereal grains [21].
This work was therefore, aimed at assessing the effect of rice bran supplementation on the physical properties, nutritional composition and sensory acceptability of wheat bread.

\section{Materials and Methods}

\subsection{Source of Materials}

About $4.0 \mathrm{~kg}$ of parboiled rice bran was obtained from Olam Nigeria Limited Rice Mill, Makurdi; while $5.0 \mathrm{~kg}$ of wheat flour and other ingredients like sugar, bakers' yeast, plasticized fat and salt were purchased from Modern Market, Makurdi, Benue State.

\subsection{Material Preparation}

The Rice bran and wheat flour were sieved to a consistent particle size $(0.50 \mathrm{~mm})$ to remove impurities such as hulls, endosperm and weed seeds. And both were packaged in a low density polyethylene bags and stored at room temperature for future use.

\subsection{Formulation of Flour Blends}

Three flour blends were prepared by mixing wheat flour with rice bran in the proportions of 95:5, 90:10 and 85:15 using a mechanical blender (Sharp EM11), while 100\% wheat flour was used as control. The four flour samples were packaged in black low density polyethylene bags and stored in $500 \mathrm{ml}$ lidded plastic containers at room temperature from where samples were taken for analysis and bread production.

\subsection{Baking Process}

Bread was baked from the flour samples using the straight dough method of Chauhan et al. [22]. All ingredients were thoroughly mixed in a dough mixer to form dough, which was put into a baking pan greased with plasticized fat and covered with greased bread wrapper. The doughs were fermented for 90 minutes at room temperature $\left(28^{\circ} \mathrm{C}-30^{\circ} \mathrm{C}\right)$, proofed at $35^{\circ} \mathrm{C}-40^{\circ} \mathrm{C}$ for 90 minutes, and baked at $250^{\circ} \mathrm{C}$ for 30 minutes. The bread loaves were packaged in low density polyethylene bags for consumption and stored at room temperature for future analysis.

\subsection{Analyses}

\subsubsection{Chemical Analyses}

The moisture, ash, crude fat, crude protein and crude fibre contents of the flours and bread samples were determined using the method of AOAC [23]. Carbohydrate was determined by difference as described by Ihekoronye and Ngoddy [24]. Mineral composition (Ca, Mg, K and $\mathrm{Fe}$ ) was determined using Atomic Absorption Spectro- 
photometer (AAS) as described by Onwuka [25]. Vitamin B (thiamine, riboflavin and niacin) were determined by High performance Liquid Chromatography (HPLC) as described by AOAC [23].

\subsubsection{Physical Analyses}

Average dough volume increase after fermentation and proofing as well as fermentation and proofing rates, were determined as described by Chauhan et al. [22]. Loaf volume was determined by the method of Giarni et al. [26], loaf weight by electronic weighing balance and specific loaf volume was calculated as (loaf volume/loaf weight).

\subsubsection{Sensory Evaluation of Bread Loaves}

Sensory evaluation of the bread samples was carried out by a panel of 20 members using a 9-point hedonic scale as described by Mellgaard [27].

\subsubsection{Statistical Analyses}

All results were subjected to analysis of variance (ANOVA) using a prepackaged computer statistical software (MINITAB 15).

\section{Results and Discussion}

\subsection{Proximate Composition}

Results of the proximate composition of the bread samples are presented in Table 1. The moisture, crude pro- tein, crude fat, crude fibre and ash contents increased significantly $(\mathrm{p}<0.05)$ from $21.07 \%$ to $23.67 \%, 12.04 \%$ to $13.10 \%, 1.57 \%$ to $3.77 \%, 1.76 \%$ to $2.91 \%$ and $1.46 \%$ to $2.41 \%$ respectively; with increased level of supplementation. This is in agreement with Farrell [17], who earlier reported that rice bran is a good source of proteins, lipids, dietary fibre and minerals and could be an effective tool in supplementing lysine and methionine deficient foods such as wheat, maize and sorghum to overcome the prevailing malnutrition problem. The carbohydrate contents decreased with increased level of supplementation from $62.10 \%$ to $54.14 \%$. This is expected since there is very little carbohydrate left in rice bran after milling.

Protein in the diet helps primarily to build and maintain body cells, while fat supplies essential fatty acids. Crude fibre plays an important role in the prevention of many diseases of the digestive tract. It has been reported that intake of more fiber results in increasing faecal bulk and lowering of plasma cholesterol [28].

\subsection{Vitamin Composition}

The B-group vitamin content of the bread samples are presented in Table 2. Thiamine and Niacin contents increased significantly $(\mathrm{p}<0.05)$ with increased level of supplementation from $0.15 \mathrm{mg} / 100 \mathrm{~g}$ to $0.47 \mathrm{mg} / 100 \mathrm{~g}$ and $3.31 \mathrm{mg} / 100 \mathrm{~g}$ to $4.04 \mathrm{mg} / 100 \mathrm{~g}$ respectively. There was also an increase in the riboflavin content from 0.06

Table 1. Proximate composition of rice bran supplemented bread samples (\%).

\begin{tabular}{ccccc}
\hline Parameter & A & B & C & DSD \\
\hline Moisture & $21.07 \pm 0.30^{\mathrm{d}}$ & $21.78 \pm 0.17^{\mathrm{c}}$ & $22.84 \pm 0.24^{\mathrm{b}}$ & $23.67 \pm 0.11^{\mathrm{a}}$ \\
Crude protein & $11.04 \pm 0.15^{\mathrm{d}}$ & $11.54 \pm 0.10^{\mathrm{c}}$ & $11.78 \pm 0.14^{\mathrm{b}}$ & $12.01 \pm 0.06^{\mathrm{a}}$ \\
Crude fat & $1.57 \pm 0.10^{\mathrm{d}}$ & $2.06 \pm 0.04^{\mathrm{c}}$ & $2.69 \pm 0.22^{\mathrm{b}}$ & $3.41 \pm 0.06^{\mathrm{a}}$ \\
Crude fibre & $1.76 \pm 0.15^{\mathrm{c}}$ & $1.84 \pm 0.08^{\mathrm{b}}$ & $2.74 \pm 0.11^{\mathrm{a}}$ & $2.91 \pm 0.07^{\mathrm{a}}$ \\
Ash & $1.46 \pm 0.11^{\mathrm{c}}$ & $1.78 \pm 0.14^{\mathrm{b}}$ & $1.84 \pm 0.06^{\mathrm{b}}$ & $2.41 \pm 0.14^{\mathrm{a}}$ \\
Carbohydrate & $63.10 \pm 0.27^{\mathrm{a}}$ & $61.00 \pm 0.25^{\mathrm{b}}$ & $58.11 \pm 0.15^{\mathrm{c}}$ & 5.22 \\
\hline
\end{tabular}

Values are means \pm standard deviation of triplicate determinations. Means in the same row with different superscripts are significantly different ( $\mathrm{p}<0.05$ ). Key: A: $100 \%$ Wheat flour (control); B: $95 \%$ wheat flour $+5 \%$ rice bran; C: $90 \%$ wheat flour $+10 \%$ rice bran; D: $85 \%$ wheat flour $+15 \%$; LSD: least significant difference.

Table 2. Vitamin content $(\mathrm{mg} / \mathbf{1 0 0 g})$ of rice bran supplemented bread samples.

\begin{tabular}{ccccc}
\hline Parameter & A & B & C & D SD \\
\hline Thiamin & $0.15 \pm 0.01^{\mathrm{d}}$ & $0.28 \pm 0.03^{\mathrm{c}}$ & $0.41 \pm 0.01^{\mathrm{b}}$ & $0.47 \pm 0.03^{\mathrm{a}}$ \\
Riboflavin & $0.06 \pm 0.00^{\mathrm{a}}$ & $0.06 \pm 0.01^{\mathrm{a}}$ & $0.07 \pm 0.01^{\mathrm{a}}$ & $0.07 \pm 0.01^{\mathrm{a}}$ \\
Niacin & $3.31 \pm 0.02^{\mathrm{d}}$ & $3.81 \pm 0.03^{\mathrm{c}}$ & $3.91 \pm 0.01^{\mathrm{b}}$ & $4.04 \pm 0.03^{\mathrm{a}}$ \\
\hline
\end{tabular}

Values are means \pm standard deviation of triplicate determinations. Means in the same row with different superscripts are significantly different $(\mathrm{p}<0.05)$ Key: A: $100 \%$ wheat flour bread (control); B: $95 \%$ wheat flour $+5 \%$ rice bran; C: $90 \%$ wheat flour $+10 \%$ rice bran; D: $85 \%$ wheat flour $+15 \%$ rice bran; LSD: least significant difference. 
$\mathrm{mg} / 100 \mathrm{~g}$ to $0.07 \mathrm{mg} / 100 \mathrm{~g}$, though not significant $(\mathrm{p}>$ $0.05)$. This could be due to the fact that rice bran is a rich source of B-vitamins as reported by Saunders [13], Farrell [17] and Dale [29].

Vitamins in food help to regulate body processes. Bgroup of vitamins, are particularly essential in carbohydrate, fat and protein metabolism. Thiamine plays a central role in the generation of energy from carbohydrates, while riboflavin is involved in the energy production for the electron transport chain, the citric acid cycle, as well as the catabolism of fatty acids. Niacin plays an important role in energy transfer reactions in the metabolism of glucose, fat and alcohol [30]. Deficiency manifests in diseases such as Beriberi, eye sensitivity, constipation, Pellagra etc.

\subsection{Mineral Composition}

Results of the mineral composition of the bread samples are presented in Table 3 . There was significantly $(\mathrm{p}<$ 0.05 ) increase in the mineral content with increased level of supplementation from $9.32 \mathrm{mg} / 100 \mathrm{~g}$ to $20.52 \mathrm{mg} / 100 \mathrm{~g}$ Iron, $80.74 \mathrm{mg} / 100 \mathrm{~g}$ to $188.20 \mathrm{mg} / 100 \mathrm{~g}$ Potassium, $81.31 \mathrm{mg} / 100 \mathrm{~g}$ to $130.70 \mathrm{mg} / 100 \mathrm{~g}$ Calcium and 13.65 $\mathrm{mg} / 100 \mathrm{~g}$ to $132.22 \mathrm{mg} / 100 \mathrm{~g}$ Magnesium, while Sodium decreased significantly $(\mathrm{p}<0.05)$ with increased level of supplementation from $305.25 \mathrm{mg} / 100 \mathrm{~g}$ to $253.03 \mathrm{mg} / 100 \mathrm{~g}$. This could be due to substitution effect caused by the high levels of minerals in rice bran as reported by Saunders [13] and Xu [16].

Minerals are vital to the functioning of many body processes. They are critical players in the functioning of the nervous system, other cellular processes, water balance and structural (e.g. skeletal) systems.

\subsection{Physical Properties of Dough and Bread Loaves}

The physical properties of dough and bread loaves are shown in Table 4. Average dough volume of the composite flours in response to fermentation and proofing decreased significantly $(p<0.05)$ with increasing proportion of rice bran from $138.33 \mathrm{~cm}^{3}$ to $118.33 \mathrm{~cm}^{3}$ and 150 $\mathrm{cm}^{3}$ to $133.33 \mathrm{~cm}^{3}$ respectively. This was also reflected in the fermentation and proofing rates of dough which decreased from $1.54 \mathrm{~cm}^{3} / \mathrm{min}$ to $1.32 \mathrm{~cm}^{3} / \mathrm{min}$ and 1.67 $\mathrm{cm}^{3} / \mathrm{min}$ to $1.48 \mathrm{~cm}^{3} / \mathrm{min}$ respectively. The loaf volume and specific loaf volume also decreased significantly $(\mathrm{p}<$

Table 3. Mineral content (mg/100g) of rice bran supplemented bread samples.

\begin{tabular}{ccccc}
\hline Parameter & A & B & C & D D \\
\hline Iron (Fe) & $9.32 \pm 0.13^{\mathrm{d}}$ & $11.40 \pm 0.19^{\mathrm{c}}$ & $15.34 \pm 0.20^{\mathrm{b}}$ & $20.52 \pm 0.30^{\mathrm{a}}$ \\
Potassium (K) & $80.74 \pm 0.09^{\mathrm{d}}$ & $110.42 \pm 0.09^{\mathrm{c}}$ & $129.25 \pm 23.08^{\mathrm{b}}$ & $188.20 \pm 0.17^{\mathrm{a}}$ \\
Sodium (Na) & $305.25 \pm 1.04^{\mathrm{a}}$ & $285.84 \pm 1.03^{\mathrm{b}}$ & $270.52 \pm 0.93^{\mathrm{c}}$ & $253.03 \pm 0.88^{\mathrm{d}}$ \\
Calcium (Ca) & $81.31 \pm 0.20^{\mathrm{d}}$ & $98.54 \pm 0.25^{\mathrm{c}}$ & $111.60 \pm 0.33^{\mathrm{b}}$ & $130.70 \pm 0.15^{\mathrm{a}}$ \\
Magnesium $(\mathrm{Mg})$ & $13.65 \pm 0.32^{\mathrm{d}}$ & $48.28 \pm 0.24^{\mathrm{c}}$ & $89.53 \pm 0.42^{\mathrm{b}}$ & 0.45 \\
\hline
\end{tabular}

Values are means \pm standard deviations from triplicate determinations. Means in the same row with different superscript are significantly different ( $\mathrm{p}<0.05$ ). Key: A: $100 \%$ wheat flour (control); B: $95 \%$ wheat flour $+5 \%$ rice bran; C: $90 \%$ wheat flour $+10 \%$ rice bran; D: $85 \%$ wheat flour $+15 \%$ rice bran; LSD: least significant difference.

Table 4. Physical properties of dough and bread loaves.

\begin{tabular}{|c|c|c|c|c|c|}
\hline Parameter & A & B & C & D & LSD \\
\hline $\begin{array}{l}\text { Average dough volume increase } \\
\text { After fermentation ( } 90 \text { mins) }\end{array}$ & $138.33 \pm 5.77^{\mathrm{a}}$ & $130.00 \pm 5.0^{\mathrm{ab}}$ & $123.33 \pm 5.77^{\mathrm{bc}}$ & $118.33 \pm 5.77^{\mathrm{c}}$ & 1.53 \\
\hline Fermentation rate $\left(\mathrm{cm}^{3} / \mathrm{min}\right)$ & $1.54 \pm 0.17^{\mathrm{a}}$ & $1.44 \pm 0.14^{\mathrm{ab}}$ & $1.37 \pm 0.17^{\mathrm{c}}$ & $1.32 \pm 0.17^{\mathrm{d}}$ & 0.03 \\
\hline $\begin{array}{l}\text { Average dough volume increase } \\
\text { after proofing ( } 90 \text { mins })\end{array}$ & $150.00 \pm 5.00^{\mathrm{a}}$ & $138.33 \pm 5.77^{\mathrm{b}}$ & $135.00 \pm 5.00^{\mathrm{b}}$ & $133.33 \pm 5.77^{\mathrm{b}}$ & 1.17 \\
\hline Proofing rate $\left(\mathrm{cm}^{3} / \mathrm{min}\right)$ & $1.67 \pm 0.20^{\mathrm{a}}$ & $1.54 \pm 0.23^{\mathrm{b}}$ & $1.50 \pm 0.20^{\mathrm{c}}$ & $1.48 \pm 0.23^{\mathrm{cd}}$ & 0.03 \\
\hline Loaf weight (g) & $152.7 \pm 1.20^{\mathrm{c}}$ & $156.0 \pm 2.00^{\mathrm{bc}}$ & $159.0 \pm 2.00^{\mathrm{ab}}$ & $162.7 \pm 2.50^{\mathrm{a}}$ & 3.37 \\
\hline Loaf volume (ml) & $655.2 \pm 1.50^{\mathrm{a}}$ & $626.3 \pm 2.50^{\mathrm{b}}$ & $604.3 \pm 1.50^{\mathrm{c}}$ & $586.0 \pm 2.00^{\mathrm{d}}$ & 3.65 \\
\hline Specific loaf volume (ml/g) & $4.29 \pm 0.03^{\mathrm{a}}$ & $4.02 \pm 0.03^{b}$ & $3.80 \pm 0.02^{\mathrm{c}}$ & $3.60 \pm 0.02^{\mathrm{d}}$ & 0.04 \\
\hline
\end{tabular}

Values are means \pm standard deviations from triplicate determinations. Means in the same row with different superscript are significantly different ( $\mathrm{p}<0.05$ ) Key: A: $100 \%$ wheat flour (control); B: $95 \%$ wheat flour $+5 \%$ rice bran; C: $90 \%$ wheat flour $+10 \%$ rice bran; D: $85 \%$ wheat flour $+15 \%$ rice bran; LSD: least significant difference. 
Table 5. Mean sensory scores of bread loaves.

\begin{tabular}{cccccc}
\hline Parameter & A & B & C & D & LSD \\
\hline Taste & $7.60^{\mathrm{a}}$ & $6.75^{\mathrm{ab}}$ & $6.20^{\mathrm{b}}$ & $5.80^{\mathrm{b}}$ & 1.35 \\
Texture & $7.90^{\mathrm{a}}$ & $6.65^{\mathrm{b}}$ & $6.20^{\mathrm{bc}}$ & $5.45^{\mathrm{c}}$ & 1.12 \\
Aroma & $7.45^{\mathrm{a}}$ & $6.40^{\mathrm{b}}$ & $5.70^{\mathrm{b}}$ & $5.60^{\mathrm{b}}$ & $5.60^{\mathrm{b}}$ \\
Crumb color & $7.60^{\mathrm{a}}$ & $6.45^{\mathrm{ab}}$ & $5.75^{\mathrm{b}}$ & $5.45^{\mathrm{c}}$ & 1.24 \\
Crust color & $8.25^{\mathrm{a}}$ & $6.55^{\mathrm{b}}$ & $5.55^{\mathrm{bc}}$ & $5.55^{\mathrm{b}}$ & 1.05 \\
Overall acceptability & $7.95^{\mathrm{a}}$ & $7.20^{\mathrm{a}}$ & $5.70^{\mathrm{b}}$ & 1.27 \\
\hline
\end{tabular}

Values are means \pm standard deviations from triplicate determinations. Means in the same row with different superscript are significantly different ( $\mathrm{p} \leq 0.05$ ). Key: A: $100 \%$ wheat flour (control); B: $95 \%$ wheat flour $+5 \%$ rice bran; C: $90 \%$ wheat flour $+10 \%$ rice bran; D: $85 \%$ wheat flour $+15 \%$ rice bran; LSD: least significant different.

$0.05)$ with increased proportion of rice bran from 655.2 $\mathrm{ml}$ to $586.0 \mathrm{ml}$ and $4.29 \mathrm{ml} / \mathrm{g}$ to $3.60 \mathrm{ml} / \mathrm{g}$ respectively. This may be attributed to the higher level of gluten present in wheat flour compared to composite blends which could not be properly stretched by carbon dioxide $\left(\mathrm{CO}_{2}\right)$ gas during fermentation and proofing [31]. This also accounts for the higher specific loaf volume found in $100 \%$ wheat flour bread (control) as compared to composite bread loaves. The loaf weight of composite bread was higher than $100 \%$ wheat flour bread (control) and this increased significantly $(\mathrm{p}<0.05)$ with increased proportion of rice bran blends from $152.7 \mathrm{~g}$ to $162.7 \mathrm{~g}$.

The increase in loaf weight might be due to the high water absorption by the rice bran and the reduced air entrapment, resulting in heavy dough. This was also reflected in the moisture content of bread loaves, with composite bread loaves giving higher moisture content than $100 \%$ wheat flour bread. According to Green and Bovel-Benjamin [32], bulky bread is desirable to hungry consumers because it is stomach filling and satisfying.

\subsection{Sensory Scores of Bread Loaves}

The sensory scores of the bread loaves are shown in Table 5 . There was a significant $(p<0.05)$ difference between the control and the composite bread in terms of texture, crumb colour, aroma, crust colour and overall acceptability. Overall acceptability was determined on the basis of quality scores obtained from the evaluation of taste, texture, aroma, crumb and crust colour. It is evident from the result that $100 \%$ wheat flour bread was more acceptable by the judges followed by composite wheat-rice bran bread with 5\%,10\% and $15 \%$ level of rice bran supplementation respectively. This could be attributed to the fact that people have been used to the quality attributes in the control food sample $(100 \%$ wheat bread).

\section{Conclusion}

Acceptable and nutritious bread was produced from composite flours of wheat and parboiled (stabilized) rice bran.
Though the $100 \%$ wheat bread was organoleptically more acceptable, the composite bread samples were more nutritious. Rice bran supplementation significantly improved the dietary fiber, mineral, vitamin (B-group) and protein content of the bread.

With the present cost of wheat, it is advantageous to seriously explore the possibility of using wheat/rice bran composite flours for commercial production of bread. This will reduce the cost of production (since rice bran is considered a waste product and is virtually free in this part of the world) and help solve the environmental problem of waste disposal.

\section{REFERENCES}

[1] O. C. Adeboye, "Proximate Composition and Nutrient Analysis of Six Selected Leafy Vegetables of South West Nigeria," Ife Journal of Agriculture, Vol. 18, No. 1-2, 1996, pp. 56-63.

[2] J. Young, "Functional Bakery Products: Current Directions and Future Opportunities," Food Industry Journal, Vol. 4, 2001, pp. 136-144.

[3] L. H. McKee and T. A. Latner, "Underutilized Sources of Dietary Fibre: A Review," Plant Foods for Human Nutrition, Vol. 55, No. 4, 2000, pp. 285-304.

[4] E. Hallen, S. Ibsnoglu and P. Anisworth, "Effect of Fermented/Germinated Cowpea Flour Addition on the Rheological and Baking Properties of Wheat Flour," Food Engineering, Vol. 63, No. 2, 2004, pp. 177-184.

[5] S. Rehman, A. Paterson, S. Hussain, M. A. Murtaza and S. Mehmood, "Influence of Partial Substitution of Wheat Flour with Vetch (Lathyrus sativus L) Flour on Quality Characteristics of Doughnuts," Leben Smitted Wissenchaffund Technologies, Vol. 40, No. 1, 2007, pp. 73-82.

[6] R. M. Junqueira, M. L. Cocato, C. Colli and L. A. Castro, "Synergisms between Lipoxygenase-Active Soybean Flour and Ascorbic Acid on Rheology and Bread Quality," Journal of Science, Food and Agriculture, Vol. 87, 2008, pp. 1172-1175.

[7] M. Arshad, F. Anjum and T. Zahoor, "Nutritional Assessment of Cookies Supplemented with Deflated Wheat Germ," Food Chemistry, Vol. 102, No. 1, 2007, pp. 123128. doi:10.1016/j.foodchem.2006.04.040 
[8] F. Koca and M. Anil, "Effect of Flaxseed and Wheat Flour Blends on Dough Rheology and Bread Quality," Journal of Science, Food and Agriculture, Vol. 87, No. 6, 2000, pp. 1172-1175. doi:10.1002/jsfa.2739

[9] B. Skrbic and B. Filipcev, "Nutritional and Sensory Evaluation of Wheat Breads Supplemented with Oleic-Rich Flower Seed," Food Chemistry, Vol. 180, No. 1, 2008, pp. 119-129. doi:10.1016/j.foodchem.2007.10.052

[10] B. A. Z. Mardiana, "Effects of Partial Substitution of Wheat Flour with Chempedak (Artocarpus integer) Seed Flour on the Physico-Chemical, Organoleptic and Microbiological Attributes of the Bread," M.Sc. Thesis, University of Sains, Malaysia, 2008.

[11] C. Q. Sharp and K. J. Kitchen, "Using Rice Bran in Yeast Bread in a Home Baker," Cereal Foods World, Vol. 35, No. 10, 1990, pp. 1021-1028.

[12] H. R. Sharma and G. S. Chauhan, "Effect of Stabilized Rice Bran-Fenugreek Blends on the Quality of Breads and Cookies," Journal of Food Science and Nutrition, Vol. 39, No. 3, 2002, pp. 225-233.

[13] R. M. Saunders, "The Properties of Rice Bran as a Food Stuff," Cereal Foods World, Vol. 35, No. 7, 1990, pp. 632-639.

[14] N. Deep, K. Yadav-Krishna and R. Singh-Jagbir, "Studies on Fortification of Wheat Flour with Defatted Rice Bran for 'Chapati' Making," Journal of Food Science and Technology, Vol. 49, No. 1, 2010, pp. 96-102.

[15] H. Hu, M. Rabinowitz and D. Smith, "Bone Lead as a Biological Marker in Epidemiological Studies of Chronic Toxicity: Conceptual Paradigms," Environmental Health Perspective, Vol. 106, No. 1, 1998, pp. 1-8. doi:10.1289/ehp.981061

[16] Z. Xu, "Purification and Antioxidant Properties of Rice Bran Y-Oryzanol Components," Ph.D. Dissertation, Louisiana State University, Baton Rouge, 1998.

[17] D. J. Farrell, "Utilization of Rice Bran in Diets for Domestic Fowls and Ducklings," World's Poultry Science Journal, Vol. 50, No. 2, 1994, pp. 115-131.

[18] L. E. Carroll, "Functional Properties and Application of Stabilized Rice Bran in Bakery Products," Journal of Food Technology, Vol. 44, 1990, pp. 74-76.

[19] J. Godber, Z. Xu, D. Hegsted and T. Walker, "Rice and Rice Bran Oil in Functional Foods Development," Louisiana Agriculture, Vol. 45, No. 4, 2004, pp. 9-10.

[20] K. S. Sekhon, S. S. Dhillon, N. Singh and B. Singh, "Functional Suitability of Commercially Milled Rice
Bran in India for Use in Different Food Products," Plant Foods for Human Nutrition, Vol. 50, No. 2, 1997, pp. 127-140. doi:10.1007/BF02436032

[21] B. Singh, K. S. Sekhon and N. Singh, "Suitability of Full Fat and Defatted Rice Bran Obtained from Indian Rice for Use in Food Products," Plant Foods for Human Nutrition, Vol. 47, No. 3, 1995, pp. 191-200.

[22] G. S. Chauhan, R. R. Zilliman and N. A. M. Eskin, "Dough Mixing and Bread Making Properties of Guinea Corn/Wheat Flour Blends," International Journal of Food Science and Technology, Vol. 27, No. 6, 1992, pp. 701705. doi:10.1111/j.1365-2621.1992.tb01241.x

[23] Association of Official Analytical Chemist, "Official Methods of Analysis," 18th Edition, Arlington, V.A., 1996, pp. 806-842.

[24] A. I. Ihekoronye and P. O. Ngoddy, "Integrated Food Science and Technology for the Tropics," Macmillan Publishers, New York, 1985, pp. 296-301.

[25] G. I. Onwuka, "Food Analysis and Instrumentation," Nphatali Press, Lagos, 2005, pp. 178-179.

[26] S. Y. Giarni, M. N. Adnindu, M. O. Akusu and J. N. T Emenike, "Compositional, Functional and Storage Properties of Flours from Raw and Heat Processed African Bread Fruit (Treculia africana Dence) Seeds," Plant Foods for Human Nutrition, Vol. 55, 2004, pp. 357-368.

[27] M. C. Meilgaard, G. V. Civille and B. T. Carr, "Sensory Evaluation Techniques," 4th Edition, C.R.C. Press L.L.C., New York, 2007.

[28] T. S. Kehlon, F. I. Chow and R. N. Sayre, "Cholesterol Lowering Properties of Rice Bran," Cereal Foods World, Vol. 39, 1994, pp. 99-103.

[29] N. Dale, "Feedstuffs Ingredient Analysis Table. Feed Stuff," Watt Publication. Co., IL, 1997, pp. 48-52.

[30] S. Gropper and J. Smith, "Advanced Nutrition and Human Metabolism," Cengage Learning Betmont, CA, 2009.

[31] O. O. Oladunmoye, R. Akinoso and A. A. Olapade, "Evaluation of Some Physic-Chemical Propreties of Wheat, Cassava, Maize and Cowpea Flours for Bread Making," Journal of Food Quality, Vol. 33, No. 6, 2010, pp. 693708. doi:10.1111/j.1745-4557.2010.00351.x

[32] J. L. Greene and A. C. Bovell-Benjamin, "Macroscopic and Sensory Evaluation of Bread Supplemented with Sweet Potato Flour," Journal of Food Science, Vol. 69, No. 4, 2004, pp. 167-173. 